\title{
Irreversible Electroporation in Interventional Oncology: Where We Stand and Where We Go
}

\section{Irreversible Elektroporation: Übersicht und Ausblick}

Authors

Affiliation
L. J. Savic, J. Chapiro, B. Hamm, B. Gebauer, F. Collettini

Radiology, Charité - Universitätsmedizin Berlin, Germany
Key words:

- irreversible electroporation

- pancreas

- lung

- prostate

- liver

- kidney

- safety

- interventional procedures

- treatment effects

- abdomen

- thorax

- ablation procedures

- ablation

\section{Zusammenfassung \\ $\nabla$}

Die irreversible Elektroporation (IRE) ist eine neuartige Gewebeablationstechnik zur bildgesteuerten lokoregionalen Tumortherapie. Im Gegensatz zu thermischen Methoden stellt die IRE ein überwiegend nicht-thermisches Ablationsverfahren dar, dessen Wirksamkeit folglich nicht durch den „heat sink effect“ limitiert wird. Ein weiterer Vorteil ist die Anwendbarkeit der IRE in Tumoren, welche unmittelbar an sensiblen Strukturen wie Gefäßnerven-Bahnen und Gallenwegen lokalisiert sind. In bisherigen Studien konnte die Durchführbarkeit der IRE in verschiedenen Tumorentitäten erfolgreich demonstriert werden. Hinsichtlich der klinischen Wirksamkeit konnten insbesondere für die Ablation in Leber-, Pankreasund Prostatatumoren erste vielversprechende Ergebnisse verzeichnet werden. Komplikationen waren insgesamt selten und traten am häufigsten durch Verletzung von Gallengängen oder Blutgefäßen und dabei eher bei IRE in Pankreas- als in Leber- oder Prostatatumoren auf. Die praktische Ausführbarkeit von IRE in der Niere wurde bisher nur in wenigen Studien gezeigt. Für den Einsatz des Verfahrens bei pulmonalen Raumforderungen konnten aufgrund eingeschränkter Durchführbarkeit bisher keine Vorteile gezeigt werden. Die folgende Übersichtsarbeit stellt eine strukturierte Zusammenfassung zum Stand der klinischen Forschung bereit und diskutiert potentielle Indikationen für IRE in der minimalinvasiven Ablationstherapie solider Tumoren.

Kernaussagen:

> Präklinisch gewonnene Erkenntnisse wurden erfolgreich in die klinische Anwendung der IRE übertragen.

> Durch nicht-thermische Ablation können „heatsink-effect“ und Koagulationsverletzungen unbeteiligter Strukturen umgangen werden.

\section{Abstract \\ $\nabla$}

Irreversible electroporation (IRE) is the latest in the series of image-guided locoregional tumor ablation therapies. IRE is performed in a nearly nonthermal fashion that circumvents the „heat sink effect" and allows for IRE application in proximity to critical structures such as bile ducts or neurovascular bundles, where other techniques are unsuitable. IRE appears generally feasible and initial reported results for tumor ablation in the liver, pancreas and prostate are promising. Additionally, IRE demonstrates a favorable safety profile. However, site-specific complications include bile leaking or vein thrombosis and may be more severe after pancreatic IRE compared to liver or prostate ablation. There is limited clinical evidence in support of the use of IRE in the kidney. In contrast, pulmonary IRE has so far failed to demonstrate efficacy due to practicability limitations. Hence, this review will provide a state-of-the-art update on available clinical evidence of IRE regarding feasibility, safety and oncologic efficacy. The future role of IRE in the minimally invasive treatment of solid tumors will be discussed.

Key points:

- Preclinical findings of IRE have been successfully translated into clinical settings.

Non-thermal ablation is able to prevent the "heat sink effect" and collateral damage.

- IRE should primarily be applied to tumors adjacent to sensitive structures (e.g. bile ducts).

$\checkmark$ IRE efficacy appears promising in the liver, pancreas and prostate with tolerable morbidity.

In contrast, there are no evidential benefits of IRE in the lung parenchyma.

Citation Format:

$\checkmark$ Savic LJ, Chapiro J, Hamm B etal. Irreversible Electroporation in Interventional Oncology: Where We Stand and Where We Go. Fortschr Röntgenstr 2016; 188: 735-745 
Die IRE sollte vorrangig bei Tumoren in unmittelbarer Umgebung sensibler Strukturen (z. B. Gallengängen) Anwendung finden.

- Insbesondere für Leber, Pankreas und Prostata zeigt die IRE eine gute onkologische Wirksamkeit bei geringer Komplikationsrate.

- Währenddessen konnten für die Anwendung bei Lungentumoren keine Vorteile der IRE gegenüber gängigen Verfahren gezeigt werden.

\section{Introduction}

Ablative therapies have become well accepted locoregional approaches in the treatment of solid tumors [1]. The latest addition to the family of ablative techniques is irreversible electroporation (IRE), which was first introduced as a novel minimally invasive ablative modality in 2005 [2]. IRE employs short electrical pulses to permanently permeabilize cell membranes resulting in homeostatic dysbalance and eventual cell death. This mechanism was extensively studied in preclinical settings where IRE has been proven to effectively ablate substantial amounts of tumor tissue. However, reported clinical experience remains sparse and mainly non-standardized.

This narrative review will provide a clinical synopsis of IRE ablation in the treatment of solid tumors. With a focus on IRE applications in the liver, pancreas, lung, kidney and prostate, achievements and limitations of non-thermal ablation in the field of image-guided therapies will be exemplified.

\section{Technical principles of IRE}

Given the term "electroporation", the mechanistic phenomenon behind IRE is based on an increase of cell membrane permeability through the application of high-voltage electrical currents. Therefore, IRE employs the positioning of adjustable needle electrodes (18G) in or around the targeted tumor under image guidance, preferably using ultrasound (US) or computed tomography $(\mathrm{CT})$. Microsecond electrical fields are utilized to alter the transmembrane potential inducing irreversible instabilities in the cell membranes. As a result, nanoscale pores ( $80-490 \mathrm{~nm})$ are formed and followed by a disruption in cell homeostasis. Eventually, cell death in IRE treatment zones occurs homogenously with a narrow transitional zone [2,3]. „Irreversible“ refers to definite cell ablation that prevents the resealing of membranes after treatment and achieves permanent permeabilization. From a clinical perspective, the implementation of irreversible ablation essentially depends on the proper setting of critical parameters such as the modifiable altitude, duration, shape, number and frequency of applied pulses [3-5].

IRE has been proven to effectively ablate tumor cells in vitro [3] as well as in vivo [6-9] with an acceptable toxicity profile. In this setting, two major methodic advantages were identified that spur on research in the field of IRE. Firstly, as opposed to the majority of ablative modalities, IRE has the remarkable characteristic of being nearly non-thermal $[2,6,10]$. Subsequently, the effect of blood flow on IRE is negligible and there will be no reduction of ablative efficacy contiguous to blood vessels through the "heat sink effect" $[2,10,11]$. This marks a momentous contrast to thermal regimes, which are substantially influenced by perfusion [12] and also limited in their application near heat-sensitive structures such as bile ducts, nerves or intestinal loops [13].
Secondly, it is of major importance for all locoregional therapies to achieve precise and well-controlled ablation of the tumor and a peritumoral safety margin while sparing healthy surrounding structures. Hence, IRE is a beneficial modality as targeted cell ablation occurs selectively with preservation of connective tissue, adjacent nerves and blood vessels within the sharply delineated ablation zone $[14,15]$. Subsequently, treatment-related complications are minimized and intact vasculature accelerates resolution of the lesions $[4,16,17]$.

\section{Clinical Considerations}

IRE is performed percutaneously or via open surgical or laparoscopic access. Usually, tumors assigned for IRE are declared unresectable and not suitable for thermal ablation due to the proximity to sensitive structures (e.g. nerves or bile ducts) [7]. Preprocedural imaging data are transferred to a pulse generator that calculates the position and number of probes based on a computer algorithm [18]. In the majority of trials, IRE was performed using NanoKnife (Angiodynamics) and configurations were set according to standard algorithms provided by the manufacturer. Usually, a series of 90 high-speed currents is administered with a duration of 20 - 100 microseconds and up to $3000 \mathrm{~V}$ $[18,19]$. Consequently, a typical session takes less than 1 minute to treat a tumor $3 \mathrm{~cm}$ in diameter and approximately 3 to $5 \mathrm{~min}$ when additional ablations are performed [17].

Despite the short ablation time, general anesthesia is mandatory as complete neuromuscular blockade is required to avoid muscle contractions triggered by the applied currents [16]. Hence, apart from site-specific complications, IRE procedures include all risks related to anesthesia $[16,19]$. In order to prevent current-related ventricular arrhythmia as a potentially severe complication, ablation pulses should be applied in an electrocardiogram (ECG)gated fashion, except for prostate ablation $[16,19]$. A recent prospective analysis of treatment-related adverse events included 28 patients who were treated with open $(n=13)$ or percutaneous $(\mathrm{n}=15)$ IRE for different abdominal tumors. Despite ECG synchronization, cardiac arrhythmia occurred in two patients during laparotomy ( $n=1$, ventricular extrasystole) and percutaneous pancreatic IRE ( $n=1$, bigeminy) but appeared to be mild without hemodynamic relevance and was self-limiting within one day [20].

In terms of follow-up, standardized criteria have not yet been defined to predict successful ablation. However, in a number of clinical trials, tumor response to IRE was determined based on the Response Evaluation Criteria in Solid Tumors (RECIST) with welldemarcated hypoattenuating ablation zones indicating successful interventions $[21,23]$ and new or persistent enhancement indicating incomplete ablation or local recurrence (LR) [18, 19, 21]. 


\section{Clinical Results}

In order to provide a status quo overview of the clinical experience reported for IRE, the bibliographic database of Pubmed was screened for prospective and retrospective original articles using the search terms "IRREVERSIBLE ELECTROPORATION", "NONTHERMAL ABLATION" and "ABLATION" in combination with synonyms for each tumor entity described below.

Liver

Thomson et al. were the first to investigate the safety and efficacy of IRE in 38 patients, 25 of whom presented with primary or secondary liver tumors (range: $1-5 \mathrm{~cm}$ ). After 63 IRE ablations, the complete response (CR) rate for hepatocellular carcinoma (HCC) was $83.3 \%$ whereas CR in colorectal liver metastases (CRM) was observed in $50 \%$ according to RECIST on 1- and 3-month followup imaging. Lesions $\geq 5 \mathrm{~cm}$ did not show significant tumor re- sponse [21]. Similarly, another prospective trial included 11 patients for percutaneous IRE in 18 HCC lesions with a diameter of $1.0-6.1 \mathrm{~cm}$. Lesions $\leq 3 \mathrm{~cm}$ required 4 ablations with repositioned needles, while bigger lesions were treated with 16 ablations per session on average. Moreover, 6 patients had received repeated treatment due to LR and intrahepatic metastases. Except for transient postprocedural pain (64\%), no complications were observed in this study. At 6 mo, response evaluation revealed CR in a total of $72 \%$ and $93 \%$ of tumors $\leq 3 \mathrm{~cm}$ and the local progression-free survival (PFS) was $18 \pm 4$ mo and the distance PFS was $14 \pm 6$ mo [24]. The previous findings are also in line with the preliminary results of a prospective multicenter phase II trial conducted by Lencioni et al. using IRE for the treatment of early stage HCC. According to RECIST, 23 out of a total of 29 tumors showed CR (79\%). Within 1 mo of follow-up, complications were rare including one case of transient hepatic decompensation and one hematothorax [25].

Table 1 Key prospective investigations of IRE for liver malignancies.

Tab. 1 Prospektive Studien zur Anwendung von IRE bei malignen Lebertumoren.

\begin{tabular}{|c|c|c|c|c|c|c|c|}
\hline $\begin{array}{l}\text { author } \\
\text { (year) }\end{array}$ & patients & target lesions & IRE & $\begin{array}{l}\text { treatment-related } \\
\text { adverse events }\end{array}$ & $\begin{array}{l}\text { follow- } \\
\text { up }\end{array}$ & results & ref. \\
\hline $\begin{array}{l}\text { Thomson } \\
\text { et al. } \\
(2011)\end{array}$ & $\mathrm{n}=38$ & $\begin{array}{l}n=25 \text { liver malig- } \\
\text { nancies including } \\
\text { CRM }(n=6) \text { and } \\
\text { HCC }(n=11) \\
\text { diameter: } 1-5 \mathrm{~cm}\end{array}$ & $\begin{array}{l}\text { percutaneous } \\
\text { image-guided } \\
\text { IRE }\end{array}$ & $\begin{array}{l}\text { transient ventricular ar- } \\
\text { rhythmia in } 4 \text { patients ( } 11 \% \text { ) } \\
\text { (electrocardiographically } \\
\text { synchronized delivery was } \\
\text { used in the remaining } 30 \text { pa- } \\
\text { tients); cardiac arrhythmia, } \\
\text { pneumothorax, brachial } \\
\text { plexus injury, pain }\end{array}$ & $\begin{array}{l}1 \text { and } 3 \\
\text { mo }\end{array}$ & $\begin{array}{l}50 \% \text { CR rate for CRM (RE- } \\
\text { CIST); } \\
83.3 \% \text { CR rate for HCC; } \\
\text { no significant tumor re- } \\
\text { sponse in lesions } \geq 5 \mathrm{~cm}\end{array}$ & 21 \\
\hline $\begin{array}{l}\text { Cheung } \\
\text { et al. } \\
(2013)\end{array}$ & $\mathrm{n}=11$ & $\begin{array}{l}\text { HCC }(n=18), \\
7 / 18 \text { lesions were } \\
\text { located adjacent } \\
\text { to sensitive struc- } \\
\text { tures } \\
\text { diameter: } 1.0- \\
6.1 \mathrm{~cm}\end{array}$ & $\begin{array}{l}\text { percutaneous } \\
\text { image-guided } \\
\text { IRE }\end{array}$ & $\begin{array}{l}\text { no major complications; } \\
\text { transient urinary retention } \\
\text { in } n=4(36 \%) \text {, } \\
\text { transient pain in } n=7(64 \%)\end{array}$ & $\begin{array}{l}14-24 \\
\text { mo }\end{array}$ & $\begin{array}{l}\text { complete ablation of } 13 \text { le- } \\
\text { sions ( } 72 \%) \text {; } \\
93 \% \text { CR rate for tumors } \leq 3 \\
\mathrm{~cm} \text {; } \\
18 \pm 4 \text { mo local PFS, } 14 \pm 6 \\
\text { distance PFS; } \\
\mathrm{n}=6 \text { ( } 55 \% \text { ) with LR and in- } \\
\text { trahepatic mets required re- } \\
\text { peated treatment }\end{array}$ & 24 \\
\hline $\begin{array}{l}\text { Lencioni } \\
\text { et al. } \\
(2012)\end{array}$ & $\mathrm{n}=26$ & $\begin{array}{l}29 \text { early-stage } \\
\mathrm{HCC} \text { lesions } \\
\leq 3 \mathrm{~cm}\end{array}$ & $\begin{array}{l}\text { percutaneous } \\
\text { image-guided } \\
\text { IRE }\end{array}$ & $\begin{array}{l}\text { no } 30 \text {-day mortality; } \\
\text { transient hepatic decom- } \\
\text { pensation ( } n=1,4 \% \text { ) with } \\
\text { spontaneous resolution and } \\
\text { hemothorax related to elec- } \\
\text { trode placement ( } n=1,4 \% \text { ) }\end{array}$ & $1 \mathrm{mo}$ & $\begin{array}{l}\text { CR in } 23(79 \%) \text {, } \\
\text { PR in } 4(13 \%), \text { SD in } 1(3 \%) \\
\text { and PD in } 1(3 \%) \text { lesions } \\
\text { (mRECIST) }\end{array}$ & 25 \\
\hline $\begin{array}{l}\text { Cannon } \\
\text { et al. } \\
(2013)\end{array}$ & $\mathrm{n}=44$ & $\begin{array}{l}\text { centrally loca- } \\
\text { ted primary or } \\
\text { secondary liver } \\
\text { tumors: } \\
\text { HCC }(n=14), \text { CRM } \\
(n=20) \text {, others } \\
(n=10) \\
\text { diameter } 2.1 \text { - } \\
2.7 \mathrm{~cm}\end{array}$ & $\begin{array}{l}\text { surgical and } \\
\text { percutaneous } \\
\text { image-guided } \\
\text { IRE }\end{array}$ & $\begin{array}{l}\text { adverse events in } n=5(11 \%) \\
\text { resolved within } 30 \text { days of } \\
\text { treatment }\end{array}$ & $\begin{array}{l}3,6 \text { and } \\
12 \mathrm{mo}\end{array}$ & $\begin{array}{l}\text { technical success in } 95 \% \text { of } \\
\text { CRM and } 100 \% \text { of HCC and } \\
\text { others; local control at } 3,6 \text {, } \\
\text { and } 12 \text { months was } 97.4 \% \text {, } \\
94.6 \% \text {, and } 59.5 \% \text {; trend to- } \\
\text { wards higher recurrence } \\
\text { rates in tumor } \geq 4 \text { cm } \\
\text { lower recurrence rates after } \\
\text { surgical probe placement }\end{array}$ & 18 \\
\hline $\begin{array}{l}\text { Eisele et } \\
\text { al. (2014) }\end{array}$ & $\mathrm{n}=14$ & $\begin{array}{l}\text { HCC }(n=5), C R M \\
(n=6), I C C(n=2) \\
\text { diameter: } 1.5 \\
\pm 0.5 \mathrm{~cm}\end{array}$ & $\begin{array}{l}\text { surgical and } \\
\text { percutaneous } \\
\text { image-guided } \\
\text { IRE }\end{array}$ & no major complications & $\begin{array}{l}3-12 \\
\text { mo }\end{array}$ & $\begin{array}{l}12 \text { ablations ( } 92 \% \text { ) were } \\
\text { technically successful; } \\
3 \text { ablations ( } 21 \% \text { ) turned out } \\
\text { to be incomplete within } 6 \\
\text { mo (all of them after percu- } \\
\text { taneous); } \\
\text { LR in tumors }>2 \mathrm{~cm} \text { and bi- } \\
\text { focal tumor sites }\end{array}$ & 26 \\
\hline
\end{tabular}


In two prospective studies, IRE was performed either via percutaneous or surgical access. In the first trial, 44 patients with centrally located HCCs $(n=14)$, CRMs $(n=20)$ and other secondary liver malignancies $(n=10)$ (range: $2.1-2.7 \mathrm{~cm}$ ) were included. Technical success was achieved in $100 \%$ of HCCs and $95 \%$ of CRM lesions. CR was reported in $100 \%$ of cases according to RECIST with a local PFS of $97.4 \%, 94.6 \%$ and $59.5 \%$ at a 3-, 6 - and 12-month follow-up, respectively. The authors observed a trend towards higher recurrence rates in tumors $>4 \mathrm{~cm}$ as well as for percutaneous probe placement [18]. The second series included 13 patients with HCC $(n=5)$, CRM $(n=6)$ and recurrent intrahepatic cholangiocarcinoma $(n=2)$ and an average tumor size of $1.5 \pm 0.5 \mathrm{~cm}$. Surgical access for IRE was combined with hepatic resection $(n=6)$. Except for one procedure, IRE was technically successful without treatment-related complications. Three ablations ( $23 \%$ ) turned out to be incomplete within $6 \mathrm{mo}$, all of which were after percutaneous approaches. Moreover, LR was observed in two other patients with tumors $>2 \mathrm{~cm}$ and in one site of a patient with bifocal ablation. Hence, the authors claim that percutaneous access, diameters exceeding $2 \mathrm{~cm}$ and CRM as an indication are associated with a higher risk of local failure [26] ( $\bullet$ Table 1 ). A number of retrospective studies focused on the effect of IRE on central hepatic structures [27, 28]. In this setting, Kingham et al. analyzed imaging-based tumor response and adverse events in 28 patients after IRE. The lesions appeared to have a small median size of $1 \mathrm{~cm}$ (range: $0.5-5 \mathrm{~cm}$ ) and were located $<1 \mathrm{~cm}$ from a major hepatic vein or portal pedicle. However, the overall morbidity was low with $3 \%$ including a single event of arrhythmia and portal vein thrombosis (PVT). As for efficacy, one patient presented with stable disease (SD) (1.9\%) at 6 mo and LR was observed in three patients (5.7\%) [29].

Overall, research on IRE in hepatic malignancies has been successfully initiated and multifaceted clinical evidence is primarily available for HCC and CRM ( $\bullet$ Fig. 1 ). With regards to this, IRE demonstrated favorable toxicity even when performed in proximity to sensitive structures and current literature suggests technical practicability and beneficial clinical outcomes, particularly for surgical access. However, lesion size remains a limiting factor for the efficacy of IRE in this setting that could possibly be countered by optimizing the number and configuration of needles.

\section{Pancreas}

Bagla et al. reported on the first case of IRE ablation in a single patient who was successfully treated for unresectable locally advanced pancreatic carcinoma (LAPC) [30]. Soon afterwards, the first prospective series was conducted to examine the safety and feasibility of IRE in 27 patients with LAPC and celiac plexus invasion who had all received previous therapies. Tumors with an average diameter of $3 \mathrm{~cm}$ were located in the pancreatic head $(n=15)$ and body $(n=12)$. Except for one case, IRE was performed via open approach. At the 90-day follow-up, imaging revealed $100 \%$ technical success and as a result, 6 patients were eligible for resection subsequent to ablation. Postprocedural complications included moderate pain and PVT as well as bile leakage and wound infection in 9 patients (33\%). One patient was lost within follow-up period. However, the authors claimed IRE to be a challenging but feasible treatment option in LAPC with acceptable morbidity [31].

In a different setting, the authors performed open IRE with concurrent resection and combined chemoradiation of LAPC in 54 patients. Compared with a matched patient group receiving chemoradiation only, the results demonstrated significantly im-
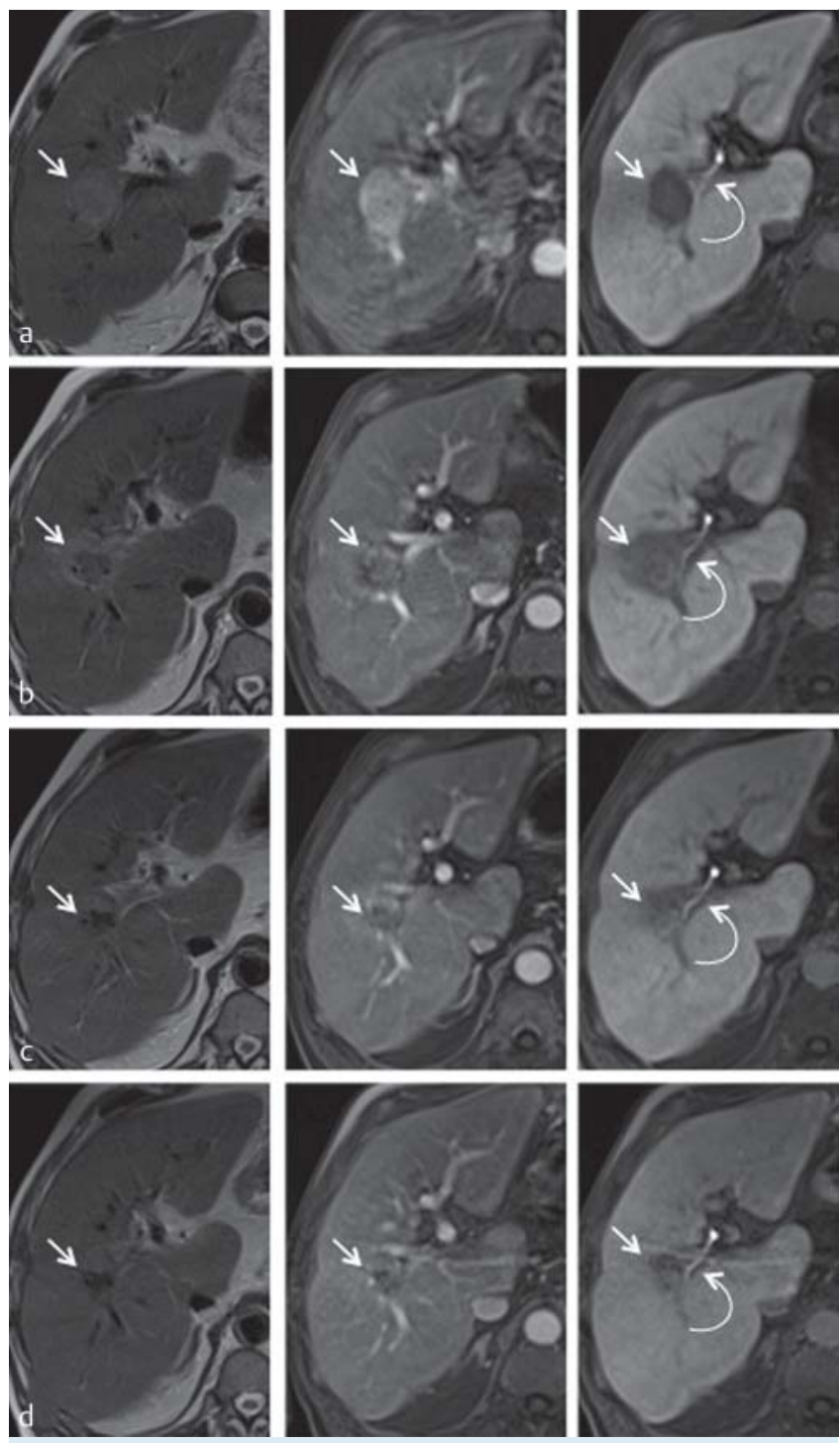

Fig. 1 Patient with unresectable hepatocellular carcinoma (HCC). Preprocedural pre- and post-contrast MRI scans a show a large HCC located close to the liver hilum. IRE was performed using five electrodes and follow-up MRI examinations at one $\mathbf{b}$, three $\mathbf{c}$ and six $\mathbf{d}$ months demonstrate progressive shrinkage of the ablation zone (arrow) with good local tumor control. Furthermore, follow-up Gd-EOB-DTPA-enhanced MRI scans show the intact bile duct (bent arrow) located in the immediate vicinity of the ablation zone.

Abb. 1 Patient mit einem unresektablen großen hilusnahen hepatozellulären Karzinom (HCC). Dargestellt sind native MRT-Bilder sowie nach Kontrastmittelgabe vor a sowie einen Monat $\mathbf{b}$, drei $\mathbf{c}$ und sechs $\mathbf{d}$ Monate nach Behandlung des HCC mittels IRE mit fünf Elektroden. Die Nachuntersuchungen zeigen eine kontinuierliche Größenabnahme des Tumors (Pfeil). Gd-EOB-DTPA-MRT-Bilder zeigen zusätzlich die intakten Gallenwege (gebogener Pfeil) in unmittelbarer Nähe zur Ablationszone.

proved PFS (14 vs. 6 mo) and overall survival (OS) (20 vs. 13 mo) [32]. Similarly, in a recent large multicenter prospective trial, 200 patients were included to investigate the efficacy of multimodal treatment approaches including IRE for the therapy of stage III LAPC. All patients received induction chemotherapy or chemoradiation followed by IRE alone $(n=150)$ or with consecutive pancreatic resection $(n=50)$. The median OS was 24.9 mo (range: 4.9-85 mo) and 6 patients (3\%) developed LR within a median follow-up of 29 mo. Compared to historical reports, the authors 
suggest a benefit for combined treatment regimens including IRE as compared to chemotherapy alone [33].

Another large prospective multicenter investigation including 107 patients with locally advanced hepatic $(n=42)$ as well as pancreatic $(\mathrm{n}=37)$ tumors with a small size of $<0.5 \mathrm{~cm}$ was published by the same group. Probes were placed percutaneously $(n=33)$ or surgically $(n=84)$ for a median number of two lesions. In terms of efficacy, a local PFS of 12.7 mo in total was reported. High grade adverse events occurred in $4.19 \%$ of cases including biliary complications and bleeding [34].

The efficacy of IRE was recently investigated in an intraoperative setting with the use of a prospective database. 48 patients with LAPC $<3.5 \mathrm{~cm}$ and a history of previous treatments were scheduled for pancreatic resection. Of a total of 44 adverse events after ablation, 5 were possibly IRE device-related and included bile leakage and PVT. No LR was observed at the 90-day follow-up. However, at 24 mo, 28 patients (58\%) showed LR and metastatic disease. The median PFS and OS were reported as 11 and 22.4 mo, respectively [35]. A smaller prospective single-center study was conducted in 10 patients with LAPC (range: $2.5-3.9 \mathrm{~cm}$ ) of the pancreatic head $(n=7)$ and body $(n=3)$ refractory to previous treatments. Regarding efficacy, tumor response according to RECIST demonstrated PR in 4 (40\%), PD in 3 (30\%) and SD in another $3(30 \%)$ patients at a median follow-up of $7.6 \mathrm{mo}$. Within 30 days, 1 patient demonstrated lung metastases and 2 patients developed liver metastases within 60 days. Complications occurred in 8 patients ( $80 \%$ ) with 1 intraoperative hypertensive episode. On day 23 after IRE, CT imaging of 1 patient (10\%) revealed a pancreatic abscess and pancreoduodenal fistula [36] (० Table 2).

In contrast to previous trials, recently published prospective data on 50 pretreated patients with pancreatic cancer (3 neuroendocrine tumors, 47 LAPC) revealed comparatively devastating perioperative morbidity and mortality for IRE as the primary treatment $(n=29)$ or margin extension procedure after surgical resection $(n=27)$. Contrary to a median OS of $12.03 \mathrm{mo}$ in the operative group, IRE for primary treatment revealed an OS of 7.71 mo. 6 patients ( $11 \%$ ) died within 90 days of follow-up and the overall recurrence rate was $58 \%$ with distant metastases occurring at a median of $9.2 \mathrm{mo}$ and local recurrence at $8.6 \mathrm{mo}$ [37].

Narayanan et al. retrospectively reported on the safety and efficacy of percutaneous IRE in 14 patients with LAPC (range: 2.5 $7 \mathrm{~cm}$ ), 3 of them with metastatic disease. All patients had received previous treatments. As for clinical outcome, 1 patient was treated twice after initial remission and LR at 7 mo. 2 other patients had local progressive disease (PD) after 1 and 2 mo, respectively, and 2 developed new metastases and 1 had metastatic progression. 6 patients demonstrated SD and 2 subsequently underwent margin-negative resections and remained disease-free after 11 and $14 \mathrm{mo}$, respectively. 1 patient developed pneumothorax and another developed transient pancreatitis. The 3 patients with metastatic disease died as a result of PD [38].

The most recent review from 2014 was designed to outline morbidity and survival after IRE in 74 patients with pancreatic cancer. 70 patients had LAPC (range: $1-7 \mathrm{~cm}$ ), and the remainder presented with metastatic disease. IRE was performed percutaneously (27\%) under US (30\%) or CT guidance ( $70 \%$ ) or surgically (70.3\% laparotomy, $2.7 \%$ laparoscopy). Regarding procedurerelated complications such as bleeding, morbidity was fairly low for IRE ablation alone but differed considerably from $0 \%$ to $33 \%$ due to varying access modalities. Depending on the study design, a 6-month survival of $40 \%$ and $70 \%$ and a PFS and OS of 14 and 20 mo, respectively, were reported. Compared to non-IRE groups
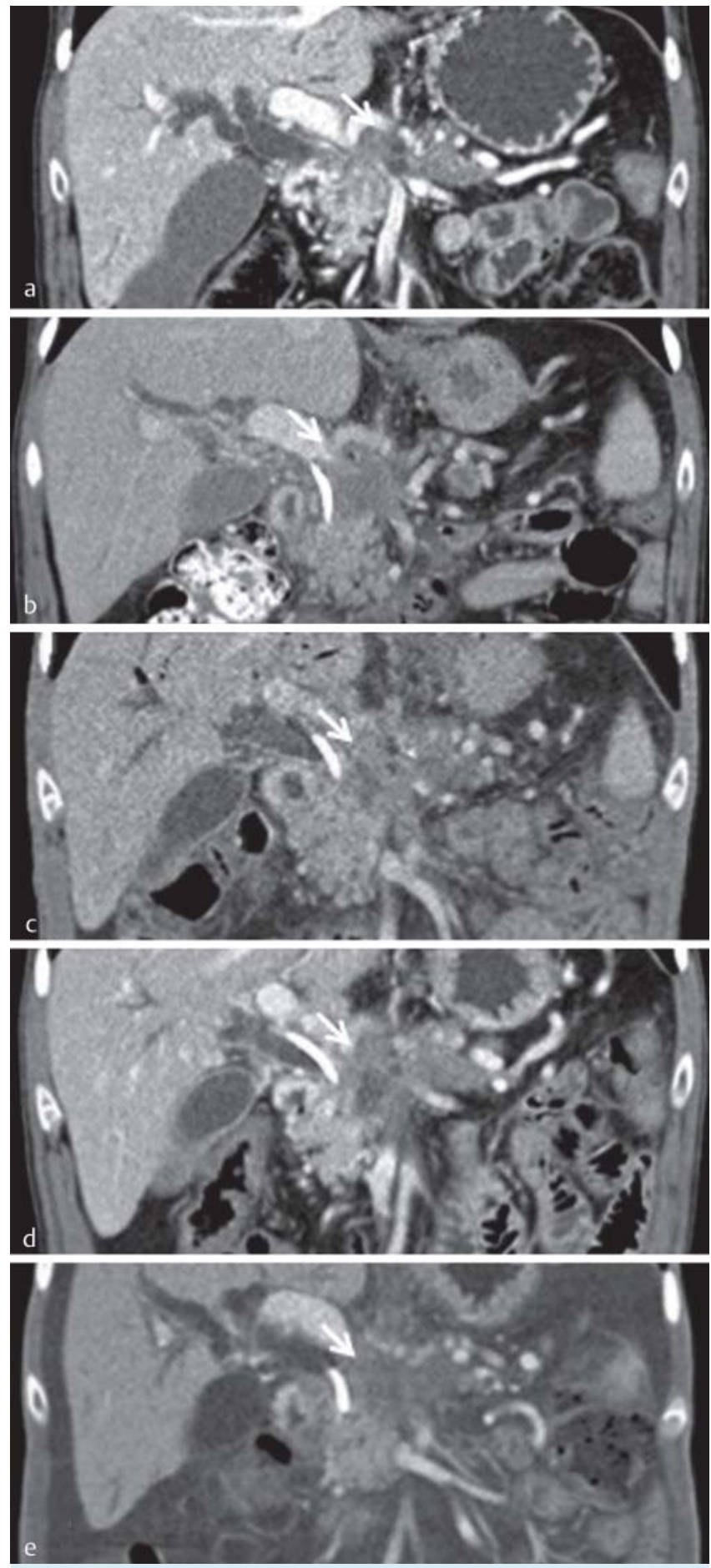

Fig. 2 Patient with locally advanced pancreatic adenocarcinoma (LAPC) (arrow) rated as unresectable by visceral surgeons. The preprocedural CT scan a shows the LAPC in the head and body of the pancreas and consecutive intrahepatic cholestasis. Follow-up CT examinations one day $\mathbf{b}$ as well as one $\mathbf{c}$, three $\mathbf{d}$ and five months $\mathbf{e}$ after IRE ablation using four electrodes show progressive shrinkage of the tumor with good local tumor control. The integrity of the nearby vessels is also confirmed by contrast-enhanced CT images.

Abb. 2 Patient mit einem als unresektabel eingestuften lokal fortgeschrittenen Pankreasadenokarzinom (LFPC) (Pfeil). Die CT-Voraufnahme a zeigt die Lokalisation des LFPC in Pankreaskopf und -korpus und eine intrahepatische Cholestase. CT-Bilder, die einen Tag b sowie einen Monat c, drei $\mathbf{d}$ und fünf Monate e nach IRE mit vier Elektroden angefertigt wurden, demonstrieren eine kontinuierliche Größenabnahme des Tumors nach der Ablation bei gleichzeitig erhaltener Integrität der umliegenden Gefäße. 
Table 2 Key prospective investigations of IRE for pancreatic cancer.

Tab. 2 Prospektive Studien zur Anwendung von IRE bei Pankreaskarzinom.

\begin{tabular}{|c|c|c|c|c|c|c|c|}
\hline $\begin{array}{l}\text { Author } \\
\text { (year) }\end{array}$ & patients & target lesions & IRE & $\begin{array}{l}\text { treatment-related } \\
\text { adverse events }\end{array}$ & $\begin{array}{l}\text { follow- } \\
\text { up }\end{array}$ & results & ref. \\
\hline $\begin{array}{l}\text { Martin } \\
\text { et al. } \\
(2012)\end{array}$ & $n=27$ & $\begin{array}{l}\text { LAPC of pancre- } \\
\text { atic head }(n=15) \\
\text { and body }(n=12) \\
\text { diameter: } 1 \text { - } \\
5.5 \mathrm{~cm}\end{array}$ & $\begin{array}{l}\text { surgical } \\
(n=26) \text { and } \\
\text { percuta- } \\
\text { neous }(n=1) \\
\text { IRE }\end{array}$ & $\begin{array}{l}9 \text { patients }(33 \%) \text { presented } \\
\text { with } 18 \text { complications includ- } \\
\text { ing pain, PVT, bile leaks, } \\
\text { wound infection; } n=4 \text { device- } \\
\text { related adverse events; } \\
90 \text {-day mortality: } n=1 \text { ( } 4 \% \text { ) }\end{array}$ & $\begin{array}{l}\text { 3-mo } \\
\text { inter- } \\
\text { vals }\end{array}$ & $\begin{array}{l}\text { no evidence of residual tu- } \\
\text { mors at } 3 \text { mo; } \\
6 \text { patients }(22 \%) \text { were eligible } \\
\text { for resection after IRE }\end{array}$ & 31 \\
\hline $\begin{array}{l}\text { Martin } \\
\text { et al. } \\
(2013)\end{array}$ & $n=139$ & $\begin{array}{l}\text { LAPC of pancre- } \\
\text { atic head }(n=35) \\
\text { and body }(n=19) \\
\text { diameter: } 1 \text { - } \\
5.5 \mathrm{~cm} \text { (for com- } \\
\text { bined treatment) }\end{array}$ & $\begin{array}{l}\text { IRE }(\mathrm{n}=54) \\
\text { combined } \\
\text { with chemo- } \\
\text { therapy or } \\
\text { radiation } \\
(47 / 54) \text { vs. } \\
\text { chemo- } \\
\text { thera-py/ra- } \\
\text { diation only } \\
(\mathrm{n}=85)\end{array}$ & $\begin{array}{l}32 / 54 \text { patients ( } 59 \%) \text { pres- } \\
\text { ented with } 67 \text { different com- } \\
\text { plications within } 90 \text { days; } \\
\text { e. g. bild leaks }(n=2) \text {, duode- } \\
\text { nal leaks }(n=2)\end{array}$ & $\begin{array}{l}\text { 3-mo } \\
\text { inter- } \\
\text { vals }\end{array}$ & $\begin{array}{l}\text { improved local PFS ( } 14 \text { vs. } \\
6 \text { mo; } p=0.01) \text { and OS ( } 20 \text { vs. } \\
13 \text { mo, } p=0.03 \text { ) compared to } \\
\text { chemotherapy/-radiation } \\
\text { only; } \\
15 / 54 \text { patients }(28 \% \text { ) had LR } \\
\text { after a median follow-up of } \\
15 \text { months }\end{array}$ & 32 \\
\hline $\begin{array}{l}\text { Martin } \\
\text { et al. } \\
(2015)\end{array}$ & $n=200$ & $\begin{array}{l}\text { radiographic } \\
\text { stage III LAPC } \\
\text { (all patients re- } \\
\text { ceived induction } \\
\text { chemotherapy or } \\
\text { chemoradiation) }\end{array}$ & $\begin{array}{l}\text { IRE alone } \\
(\mathrm{n}=150) \text { or } \\
\text { combined } \\
\text { with pancre- } \\
\text { atic resec- } \\
\text { tion }(n=50)\end{array}$ & $\begin{array}{l}37 \% \text { of patients reported } \\
\text { complications }\end{array}$ & $\begin{array}{l}\text { medi- } \\
\text { an: } 29 \\
\text { mo }\end{array}$ & $\begin{array}{l}\mathrm{n}=6(3 \%) \text { had LR; } \\
\text { median OS was } 24.9 \text { mo (4.9- } \\
85 \text { mo) } \\
\text { prolonged survival compared } \\
\text { to chemotherapy/-radiation } \\
\text { only (historical reports) }\end{array}$ & 33 \\
\hline $\begin{array}{l}\text { Martin } \\
\text { et al. } \\
(2014)\end{array}$ & $n=107$ & $\begin{array}{l}\text { advanced hepatic } \\
\text { malignancies } \\
(\mathrm{n}=42) \text { and LAPC } \\
(\mathrm{n}=37) \\
\text { diameter: } \\
<0.5 \mathrm{~cm}\end{array}$ & $\begin{array}{l}\text { surgical } \\
(\mathrm{n}=84) \text { and } \\
\text { percuta- } \\
\text { neous } \\
(\mathrm{n}=33) \text { IRE }\end{array}$ & $\begin{array}{l}43 \text { patients ( } 40 \% \text { ) with } 84 \\
\text { complications; high-grade } \\
\text { adverse events in } 21 \text { patients } \\
(19 \% \text { ) with } n=19 \text { attributable } \\
\text { to IRE; } \\
\text { increased complication rate } \\
\text { after surgical IRE; } \\
90 \text {-day mortality: } n=2(2 \%)\end{array}$ & $\begin{array}{l}\text { 3-mo } \\
\text { inter- } \\
\text { vals } \\
\text { (medi- } \\
\text { an: } 29 \\
\text { mo) }\end{array}$ & $\begin{array}{l}\mathrm{n}=12(4.7 \%) \text { incomplete ab- } \\
\text { lations; } \\
\text { inverse association of LR-free } \\
\text { survival and lesion size } \\
(\mathrm{p}=0.02) \text {; } \\
\mathrm{n}=7(5.9 \%) \text { with persistent } \\
\text { disease at } 3 \text {-mo follow-up re- } \\
\text { ceived re-ablation; } \\
\text { local PFS was } 12.7 \text { mo; } \\
\text { median time to LR was } 12 \text { mo } \\
\text { (liver) and } 16 \text { mo (LAPC) }\end{array}$ & 34 \\
\hline $\begin{array}{l}\text { Kwon } \\
\text { et al. } \\
(2014)\end{array}$ & $n=48$ & $\begin{array}{l}\text { LAPC } \\
\text { diameter: } \\
<3.5 \mathrm{~cm}\end{array}$ & $\begin{array}{l}\text { intraopera- } \\
\text { tive IRE }\end{array}$ & $\begin{array}{l}\mathrm{n}=5 \text { treatment-related com- } \\
\text { plications including bile leak- } \\
\text { age and PVT }\end{array}$ & $24 \mathrm{mo}$ & $\begin{array}{l}\text { no recurrence within } 90 \text { days; } \\
\text { LR and metastases in } n=52 \\
(58 \% \text { ) after } 24 \text { mo; } \\
\text { median PFS was } 11 \text { mo and OS } \\
\text { was } 22.4 \text { mo }\end{array}$ & 35 \\
\hline $\begin{array}{l}\text { Paiella } \\
\text { et al. } \\
(2015)\end{array}$ & $\mathrm{n}=10$ & $\begin{array}{l}\text { LAPC of pancre- } \\
\text { atic head }(n=7) \\
\text { and body }(n=3) \\
\text { refractory to pre- } \\
\text { vious treatments } \\
\text { diameter: } 2.5 \text { - } \\
3.9 \mathrm{~cm}\end{array}$ & surgical IRE & $\begin{array}{l}\text { pancreatic abscess with pan- } \\
\text { creoduodenal fistula in } 1 \mathrm{pa-} \\
\text { tient }(10 \%) \text { on post-treatment } \\
\text { day } 23 \text {; } \\
\mathrm{n}=1(10 \%) \text { hypertensive epi- } \\
\text { sode intraoperative; } \\
13 \text { complications in } 8 \text { patients } \\
(80 \%)\end{array}$ & $\begin{array}{l}\text { median } \\
7.6 \text { mo } \\
\text { (weekly } \\
\text { for } 90 \\
\text { days, } \\
\text { then } \\
\text { quar- } \\
\text { terly) }\end{array}$ & $\begin{array}{l}\text { lung metastases within } 30 \\
\text { days ( } n=1,10 \% \text { ), liver metas- } \\
\text { tases within } 60 \text { days ( } n=2 \text {, } \\
20 \% \text { ); } \\
\text { OS was } 7.5 \text { mo (range, } 2.5 \text { - } \\
15.9 \text { mo); } \\
n=9 \text { died from disease, } n=1 \\
\text { died of septic shock } 2 \text { weeks } \\
\text { after IRE; } \\
\text { PR in } n=4(40 \%) \text {, PD in } n=3 \\
(30 \%) \text { and SD in } n=3(30 \%) \\
\text { (RECIST) }\end{array}$ & 36 \\
\hline $\begin{array}{l}\text { Kluger } \\
\text { et al. } \\
(2015)\end{array}$ & $n=50$ & $\begin{array}{l}\operatorname{LAPC}(n=47) \text { and } \\
\text { neuroendocrine } \\
\text { pancreatic tu- } \\
\text { mors }(n=3) \\
\text { diameter: } \leq 3 \mathrm{~cm}\end{array}$ & $\begin{array}{l}\text { IRE for pri- } \\
\text { mary treat- } \\
\text { ment and for } \\
\text { margin ex- } \\
\text { tension } \\
\text { combined } \\
\text { with surgery }\end{array}$ & $\begin{array}{l}\mathrm{n}=13(26 \%) \text { grade } 1 \text { and } 2 \\
\text { complications within } 30 \text { days; } \\
\text { e. g. bleeding, gastric ulcer } \\
\text { perforation, bile duct stric- } \\
\text { tures and necrosis; } \\
\text { no correlation between com- } \\
\text { plications (grade } 3-5 \text { ) and } \\
\text { adjustable parameters of IRE }\end{array}$ & $\begin{array}{l}\text { median } \\
8.69 \\
\text { mo }\end{array}$ & $\begin{array}{l}\text { OS was } 12.03 \text { mo after surgery } \\
\text { and } 7.71 \text { mo after primary IRE } \\
\text { treatment; } \\
\text { overall recurrence rate was } \\
58 \%: 47 \% \text { distant (median } 9.2 \\
\text { mo) and } 11 \% \text { local recurrence } \\
\text { (median } 8.6 \text { mo) }\end{array}$ & 37 \\
\hline
\end{tabular}


(PFS of 6 and OS of $11 \mathrm{mo}$ ), a prognostic benefit for IRE became apparent [39].

To sum up, IRE has repeatedly proven to prevent recurrence and hold back local progression with a prognostic benefit in patients with LAPC ( $\boldsymbol{0}$ Fig. 2 ). It is particularly encouraging that some studies report cases of patients who could be transferred to resection after IRE. Major complications included PVT and bile leaks but the overall morbidity was tolerable.

\section{Lung}

Besides the liver and kidney, IRE was also performed in the lung in 3 patients (CRM, breast cancer metastasis, non-small cell lung cancer (NSCLC)) in a prospective setting. This early case series by Thomson et al. examined the efficacy and safety of the procedure as described earlier in this review. However, as opposed to liver tumors, all patients presented with PD at a 1- and 3-month follow-up according to RECIST. As revealed by biopsy, treatment failure occurred as a result of incomplete ablation. 2 patients developed pneumothoraces related to central lung ablation that resolved spontaneously. 1 patient was lost within the follow-up period [21].

Another case series reported on the IRE treatment of 2 patients with lung malignancies. The first patient presented with a hilar sarcoma metastasis $(2.3 \times 2.4 \times 1.7 \mathrm{~cm})$ and the second patient had suprahilar non-small cell lung cancer (NSCLC; $2.1 \times 1.9 \times 2.1 \mathrm{~cm}$ ) and comorbid radiogenic pulmonary fibrosis. At a 6- and 2month follow-up, CT and PET/CT imaging revealed LR and even PD similar to the previously described study. Subsequently, the authors postulated the failure of IRE in lung parenchyma due to limited feasibility [40].

The first controlled prospective study was a recent multicenter phase II trial (ALICE) to investigate the safety and efficacy of IRE in primary and secondary lung malignancies, mainly CRM $(n=13)$. Initially, 36 patients with previous treatments but normal lung function were included but the study was terminated early after the treatment of 23 patients. Treated target lesions measured a median diameter of $1.6 \mathrm{~cm}$ (range: $0.8-2.7 \mathrm{~cm}$ ). As for major complications, 11 patients developed pneumothoraces, 8 of which required chest tubes. Regarding efficacy, 7 patients showed CR (39\%), 1 had partial remission (4\%), 1 had SD (4\%) and 14 developed PD (61\%) at a 3-month follow-up using CT and PET/CT. As precise parallel probe alignment was limited by the thoracic cavity, effective ablation could not be guaranteed and IRE eventually failed to demonstrate efficacy in this setting. Moreover, needle tract seeding was observed in 3 cases (13\%) [41].

Mainly due to fundamental feasibility limitations, IRE has so far failed to prove efficacy in lung parenchyma. Common complications included pneumothoraces in numerous patients.

\section{Kidney}

Pech et al. reported the first-in-man phase I clinical trial to examine the feasibility and safety of intraoperative IRE in 6 patients with local renal cell carcinoma (RCC) who were scheduled for curative tumor resection. IRE was performed approximately 15 minutes prior to surgery. Except for one minor arrhythmia, no adverse effects were recorded within the short-term follow-up period of 12 weeks. However, immediate biopsy could not demonstrate cell death in the specimens [42].

A recent pilot study ("IRENE trial") to investigate the histopathological effects of IRE included 3 patients with localized RCC (T1a; range: $1.5-1.7 \mathrm{~cm})$ in a central $(\mathrm{n}=1)$ or peripheral $(\mathrm{n}=2)$ loca-

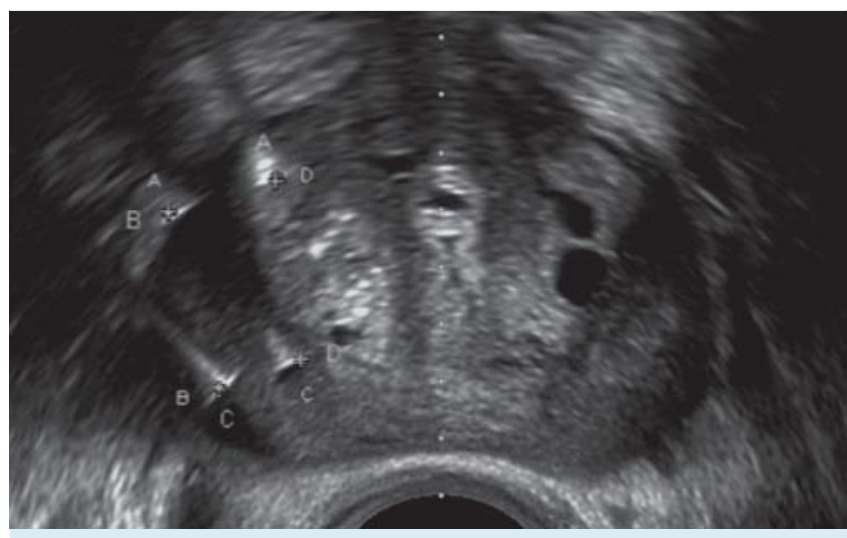

Fig. 3 Unenhanced transrectal ultrasound (TRUS) imaging during IRE ablation of a small prostate cancer lesion (Gleason score: $3+3=6$ ) of the right lobe shows four electrode tips that are placed in parallel alignment and encompass the tumor.

Abb. 3 Dargestellt sind transrektale Ultraschallbilder eines kleinen Prostatakarzinoms (Gleason Score: $3+3=6$ ) im rechten Prostatalappen während einer IRE-Ablation mit vier parallelen Elektroden.

tion. Focal IRE was performed in a percutaneous fashion 4 weeks prior to renal resection. Contrary to an expected homogenous ablation zone, ex vivo analyses revealed structuring of the treated area with central necrosis surrounded by tissue that was secondarily damaged by nutritive deprivation. Additionally, 2 resected tissues demonstrated residual tumor satellites within the ablation zone [43].

Thomson et al. performed IRE of 11 renal tumors (RCC, $n=11$; other tumors, $n=4$ ) with a median tumor size of 2.7 (range: $1.6-5.3 \mathrm{~cm}$ ). The primary efficacy was $45 \%$ and CR was achieved in RCC lesions. The authors reported on 1 case of accidental adrenal ablation followed by severe hypotension for $2 \mathrm{mo}$ and hematuria in 2 patients after central IRE [21].

However, IRE for the treatment of RCC proved feasible and safe in the presented trial but prospective efficacy studies on IRE are warranted.

\section{Prostate}

Onik et al. reported the first case series including 16 patients with unifocal prostate cancer of varying Gleason scores. Based on preprocedural biopsies, the cancer loci were targeted under transrectal US (TRUS) guidance ( $\bullet$ Fig. 3). IRE was well tolerated in all patients. Immediate postprocedural Doppler US revealed the preservation of the neurovascular bundle and continence and potency remained unaffected in all patients. At a 3-week followup, biopsies of the ablation zone showed necrotic and fibrotic tissue with no evidence of cancer in 15 patients and one micro-focus of Gleason 6 cancer outside the treated area [44].

Brausi et al. presented the results of a prospective IRE pilot study in 11 patients with low-risk prostate cancer. They reported no major intraprocedural complications. However, during the follow-up, 1 patient had acute urinary retention and 3 presented with transient incontinence. After $1 \mathrm{mo}$, histopathological reports were negative in 8 patients (73\%) showing coagulative necrosis and fibrosis. 3 patients had residual disease and 2 of them underwent second IRE ablation [45].

With special regard to the technical success of ablation procedures, a multicenter prospective trial reporting on 16 men who were treated with IRE for localized prostate cancer 4 weeks prior 
Table 3 Key investigations of IRE for prostate cancer.

Tab. 3 Studien zur Anwendung von IRE bei Prostatakarzinom.

\begin{tabular}{|c|c|c|c|c|c|c|c|}
\hline $\begin{array}{l}\text { author } \\
\text { (year) }\end{array}$ & patients & target lesions & IRE & $\begin{array}{l}\text { treatment-related } \\
\text { adverse events }\end{array}$ & $\begin{array}{l}\text { follow- } \\
\text { up }\end{array}$ & results & ref. \\
\hline $\begin{array}{l}\text { Onik } \\
\text { et al. } \\
(2010)\end{array}$ & $\mathrm{n}=16$ & $\begin{array}{l}\text { unifocal prostate } \\
\text { cancer; varying } \\
\text { Gleason scores }\end{array}$ & $\begin{array}{l}\text { TRUS-guid- } \\
\text { ed IRE }\end{array}$ & no complications & 3 weeks & $\begin{array}{l}\text { biopsies }(n=15) \text { revealed uni- } \\
\text { form destruction of glandular } \\
\text { cellular elements and reactive } \\
\text { fibrosis within ablation zone; } \\
\text { microfocus of Gleason } 6 \text { lesion } \\
\text { outside ablation area ( } n=1 \text {, } \\
6 \% \text { ); } \\
\text { preservation or recurrence of } \\
\text { continence and potency } \\
(100 \%) \text { (Doppler-US) }\end{array}$ & 44 \\
\hline $\begin{array}{l}\text { Brausi } \\
\text { et al. } \\
(2011)\end{array}$ & $\mathrm{n}=11$ & $\begin{array}{l}\text { low-risk prostate } \\
\text { cancer; varying } \\
\text { Gleason scores }\end{array}$ & & $\begin{array}{l}\text { transient incontinence }(n=3 \text {, } \\
27 \%) \text {, acute urinary retention } \\
(n=1,9 \%)\end{array}$ & $1 \mathrm{mo}$ & $\begin{array}{l}\text { histopathological analysis re- } \\
\text { vealed coagulative necrosis } \\
\text { and fibrosis in } n=8(73 \%) \text { and } \\
\text { residual disease in } n=3(27 \%) \\
\text { with } 2 \text { patients being repeat- } \\
\text { edly treated }\end{array}$ & 45 \\
\hline $\begin{array}{l}\text { Van den } \\
\text { Bos } \\
\text { et al. } \\
(2015)\end{array}$ & $n=16$ & $\begin{array}{l}\text { localized pros- } \\
\text { tate cancer } \\
\text { (scheduled for } \\
\text { radical prosta- } \\
\text { tectomy) }\end{array}$ & $\begin{array}{l}\text { TRUS-guid- } \\
\text { ed focal } \\
(n=6) \text { or ex- } \\
\text { tended } \\
(n=10 ; \geq 4 \\
\text { electrodes) } \\
\text { IRE }\end{array}$ & no serious adverse events & $\begin{array}{l}4 \text { weeks } \\
\text { (prior } \\
\text { to sur- } \\
\text { gery) }\end{array}$ & $\begin{array}{l}100 \% \text { complete ablation with } \\
\text { histopathologically confirmed } \\
\text { necrosis and fibrosis within } \\
\text { sharply demarcated ablation } \\
\text { zone, no skip lesions; correla- } \\
\text { tion of needle configuration } \\
\text { with ablation zone }\end{array}$ & 47 \\
\hline $\begin{array}{l}\text { Ting } \\
\text { et al. } \\
(2015)\end{array}$ & $n=25$ & $\begin{array}{l}\text { low-intermediate } \\
\text { risk prostate can- } \\
\text { cer }\end{array}$ & & $\begin{array}{l}\text { no alterations of urinary, sex- } \\
\text { ual or bowel function accord- } \\
\text { ing to clinical examinations } \\
\text { and questionnaires }\end{array}$ & $8 \mathrm{mo}$ & $\begin{array}{l}\text { no suspicious findings within } \\
\text { ablation zone on mp-MRI } \\
(n=24) \text { or biopsy }(n=21) \text { in all } \\
\text { patients; } n=5(21 \%) \text { had sus- } \\
\text { picious findings adjacent to } \\
\text { treatment zone on mp-MRI } \\
\text { with } n=4(19 \%) \text { confirmed by } \\
\text { biopsy; } n=2(8 \%) \text { with suspi- } \\
\text { cious findings outside of abla- } \\
\text { tion zone on mp-MRI and } n=1 \\
(5 \%) \text { approved by biopsy }\end{array}$ & 49 \\
\hline $\begin{array}{l}\text { Valerio } \\
\text { et al. } \\
(2014)\end{array}$ & $\begin{array}{l}\mathrm{n}=34 \\
\text { (retro- } \\
\text { spective } \\
\text { analysis) }\end{array}$ & $\begin{array}{l}\text { localized pros- } \\
\text { tate cancer } \\
\text { low }(26 \%) \text {, inter- } \\
\text { mediate }(71 \%) \text {, } \\
\text { high ( } 3 \%) \text { risk }\end{array}$ & $\begin{array}{l}\text { TRUS-guid- } \\
\text { ed }\end{array}$ & $\begin{array}{l}\mathrm{n}=12(35 \%) \text { grade } 1 \\
\mathrm{n}=10(29 \%) \text { grade } 2 \text { adverse } \\
\text { events }\end{array}$ & $\begin{array}{l}1-24 \\
\text { mo, } \\
\text { median } \\
6 \text { mo }\end{array}$ & $\begin{array}{l}\text { preservation of continence } \\
(100 \%) \text { and potency }(95 \%) ; \\
\text { ablation volume: } 5.6-14.5 \\
\text { ml; } \\
\text { suspicious residual disease in } \\
\mathrm{n}=6(18 \%) \text { after } 6 \text { mo with } 3 \\
\text { patients being repeatedly } \\
\text { treated }\end{array}$ & 51 \\
\hline
\end{tabular}

to radical prostatectomy was recently published. Within the short follow-up period, no serious adverse events occurred. The histopathological examination of the harvested tissue revealed complete necrosis and fibrosis of the ablation zone which corresponded well with the configuration of needle placement for focal $(n=6)$ or extended ( $n=10 ; \geq 4$ electrodes) IRE $[46,47]$. Additionally, CEUS and T2-weighted MRI were found to be adequate imaging modalities to visualize the effects of IRE as they correlated well with the results of the histopathological analysis [48].

Another single-center prospective trial included 25 patients with low-intermediate-risk prostate cancer, who were followed up for 8 mo with various clinical examinations as well as mpMRI and biopsies. Analysis of the ablation zone did not reveal suspicious findings for residual disease, whereas 4 patients (19\%) demonstrated pathologically confirmed residual tumor adjacent to the treatment zone and 1 patient (5\%) had suspicious findings outside the ablation area [49].
A recent two-center retrospective analysis investigated the local safety of transperineal IRE and included 34 patients with localized prostate cancer. The maximum cancer length was $0.6 \pm 0.3 \mathrm{~cm}$. Electrodes were placed under TRUS guidance around the lesion. In terms of safety, a median standardized [50] clinical follow-up of 6 mo revealed 12 (35\%) grade 1, 10 (29\%) grade 2 and no severe grade 3 complications. From a functional point of view, continence was preserved in $100 \%(24 / 24)$ and potency in $95 \%(19 /$ 20 ) of patients. Multiparametric ( $\mathrm{mp}$ ) MRI after 6 mo demonstrated suspicious residual disease in 6 patients, 3 of whom underwent another form of local treatment [51] ( $\bullet$ Table 3).

In conclusion, clinical experience with the use of IRE in prostate cancer is relatively limited but further results of prospective analyses in larger cohorts are forthcoming [52]. So far, safety reports on transperineal IRE state favorable safety, and clinical followups demonstrate preserved continence and potency. However, prospective oncologic efficacy studies are sorely needed to finally 

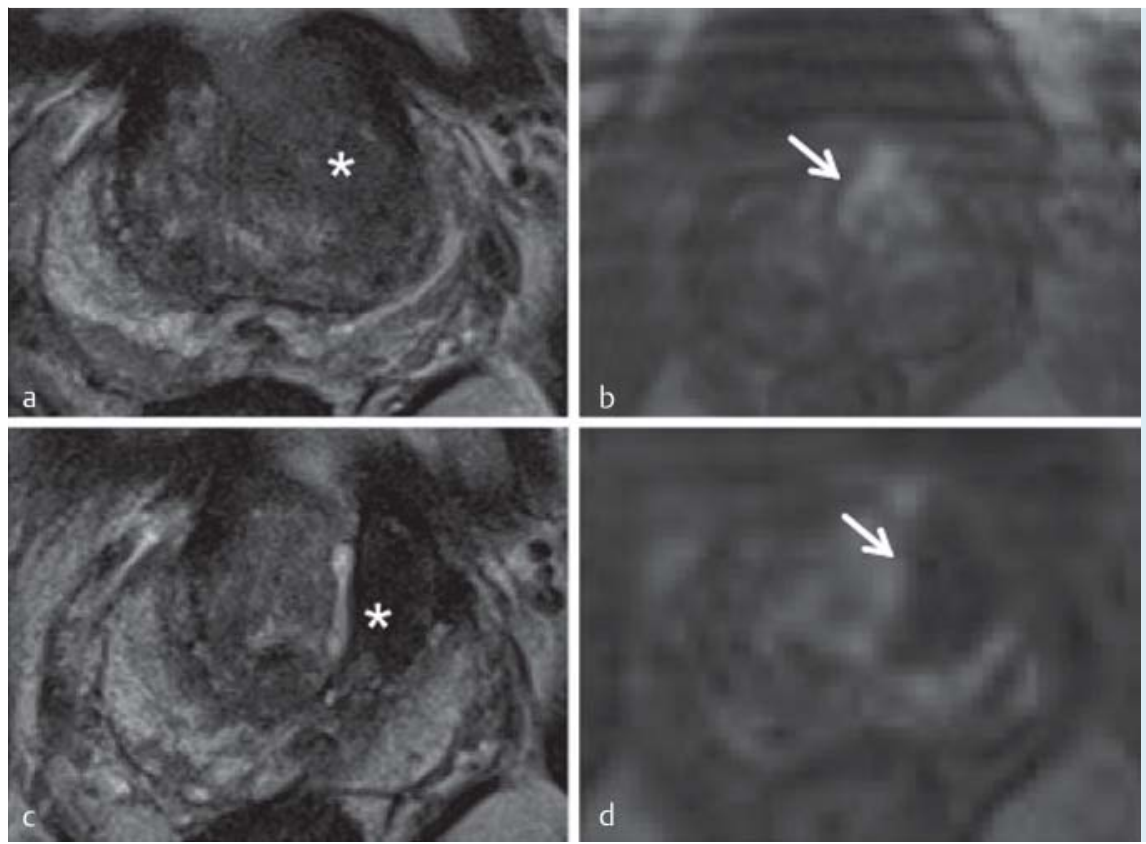

d
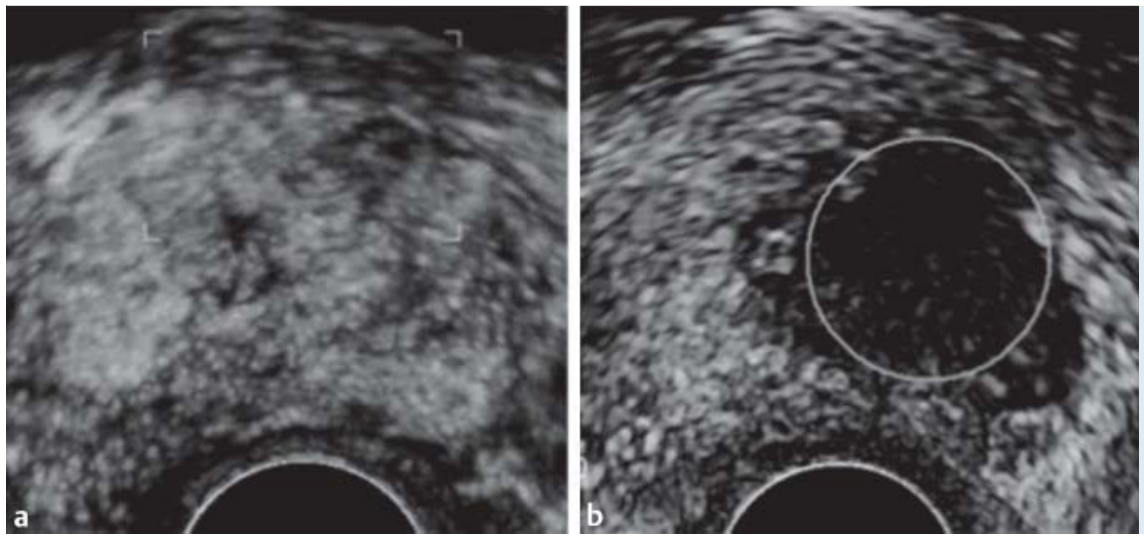

Fig. 4 Patient with prostatic cancer $\left({ }^{*}\right)$ (Gleason score: $3+3=6$ ) in the transitional zone treated with ultrasound-guided IRE. The preprocedural precontrast $\mathbf{a}$ and postcontrast $\mathbf{b}$ MRI scans show the tumor in the ventral left prostatic lobe. Follow-up MRI examinations six months after IRE demonstrate a hypointense area in the ablation zone $\mathbf{c}$ and a sharply demarcated perfusion defect in the same area $\mathbf{d}$ (arrow) on T2-weighted images.

Abb. 4 Patient mit Prostatakarzinom (*) (Gleason Score: $3+3=6$ ) in der Transitionalzone erhält eine Ultraschall-gestützte IRE-Behandlung. Native a und Kontrastmittel-MRT-Voraufnahmen b zeigen die Lokalisation des Tumors im ventralen Anteil des linken Prostatalappens. MRT-Bilder sechs Monate nach IRE weisen ein hypointenses Areal $\mathbf{c}$ und einen scharf abgrenzbaren Perfusionsdefekt $\mathbf{d}$ (Pfeil) in der Ablationszone auf den T2-gewichteten Sequenzen auf. establish IRE in the prostate as a new technique for locoregional tumor therapy ( $\bullet$ Fig. 4,5 ).

\section{Conclusion and Future Directions \\ $\nabla$}

Preclinical findings of IRE have been translated into clinical settings. At present, IRE appears to be filling a niche for the ablation of tumors in proximity to critical structures such as the hilus region or large vessels where either the heat sink effect or collateral damage constitute a concern for thermal ablation and resection. With respect to efficacy, the results of IRE found in this review appear promising in the liver, pancreas, and prostate where the overall morbidity is also tolerable. In terms of safety, no attributed mortality has been reported so far and mainly mild transient side effects such as postprocedural pain similar to radiofrequency ablation occur [53]. On the contrary, there is no evidential benefit of IRE in the lung parenchyma. In this setting, feasibility is limited and pneumothoraces occur as frequent potentially severe complications. Regarding renal IRE, no definite conclusion can be drawn here due to limited data. However, Pech et al. reported successful performance of IRE in the kidney with a favorable safety profile [41].

Overall, one of the shortcomings of IRE today remains the absence of clinically validated protocols to be used in different tumor entities. Current literature only provides a low level of evidence as the presented studies are mostly small case series or heterogeneously designed reports without control groups. IRE has so far been applied with palliative intent but may also be a feasible adjuvant procedure in resectable tumors. With regard to this, randomized controlled trials are required to determine IRE indication in a continuously growing armamentarium of locoregional therapies.

\section{Acknowledgments}

The authors would like to thank Dr. Leo Pallwein-Prettner for kindly donating some of the images of the present article. 


\section{References}

1 Lencioni R, Crocetti L, Narayanan G. Irreversible Electroporation in the Treatment of Hepatocellular Carcinoma. Tech Vasc Interv Radiol 2015; 18: 135 -139. PubMed PMID: 26365542

2 Davalos RV, Mir IL, Rubinsky B. Tissue ablation with irreversible electroporation. Ann Biomed Eng 2005; 33: 223-231. PubMed PMID: 15771276

3 Miller L, Leor J, Rubinsky B. Cancer cells ablation with irreversible electroporation. Technol Cancer Res Treat 2005; 4: 699-705. PubMed PMID: 16292891

4 Rubinsky B, Onik G, Mikus P. Irreversible electroporation: a new ablation modality-clinical implications. Technol Cancer Res Treat 2007; 6: 37-48. PubMed PMID: 17241099

5 Ben-David E, Appelbaum L, Sosna J et al. Characterization of irreversible electroporation ablation in in vivo porcine liver. Am J Roentgenol 2012; 198: W62-W68. DOI: 10.2214/AmJRoentgenol.11.6940. PubMed PMID: 22194517

6 Al-Sakere B, André F, Bernat $C$ et al. Tumor ablation with irreversible electroporation. PLoS One 2007; 2: e1135. DOI: 10.1371/journal. pone.0001135. PubMed PMID: 17989772; PMCID: PMC2065844

7 Edd JF, Horowitz L, Davalos RV et al. In vivo results of a new focal tissue ablation technique: irreversible electroporation. IEEE Trans Biomed Eng 2006; 53: 1409-1415. DOI: 10.1109/TBME.2006.873745. PubMed PMID: 16830945

8 Lee $E W$, Wong $D$, Tafti BA et al. Irreversible electroporation in eradication of rabbit VX2 liver tumor. J Vasc Interv Radiol 2012; 23 (6): 833 40. doi: 10.1016/j.jvir.2012.02.017. PubMed PMID: 22534357

9 Charpentier KP, Wolf F, Noble L et al. Irreversible electroporation of the liver and liver hilum in swine. HPB (Oxford) 2011; 13: 168-173. DOI: 10.1111/j.1477-2574.2010.00261.x. PubMed PMID: 21309933; PMCID: PMC3048967

10 Faroja $M$, Ahmed $M$, Appelbaum L et al. Irreversible electroporation ablation: is all the damage nonthermal? Radiology 2013; 266 (2): 462 470. DOI: 10.1148/radiol.12120609. PubMed PMID: 23169795

11 Goldberg SN, Hahn PF, Halpern EF et al. Radio-frequency tissue ablation: effect of pharmacologic modulation of blood flow on coagulation diameter. Radiology 1998; 209 (3): 761 - 767. DOI: 10.1148/radiology.209.3.9844671. PubMed PMID: 9844671

12 Mertyna P, Goldberg W, Yang W et al. Thermal ablation a comparison of thermal dose required for radiofrequency-, microwave-, and laser-induced coagulation in an ex vivo bovine liver model. Acad Radiol 2009; 16: 1539-1548. DOI: 10.1016/j.acra.2009.06.016. PubMed PMID: 19836267; PMCID: PMC2784236

13 Rubinsky B. Irreversible electroporation in medicine. Technol Cancer Res Treat 2007; 6: 255-260. PubMed PMID: 17668932

14 Livraghi T, Meloni F, Solbiati L et al. Complications of microwave ablation for liver tumors: results of a multicenter study. Cardiovasc Intervent Radiol 2012; 35: 868-874. DOI: 10.1007/s00270-011-0241-8. PubMed PMID: 21833809

15 Maor E, Ivorra A, Leor J et al. The effect of irreversible electroporation on blood vessels. Technol Cancer Res Treat 2007; 6: 307-312 PubMed PMID: 17668938

16 Ball C, Thomson KR, Kavnoudias H. Irreversible electroporation: a new challenge in "out of operating theater" anesthesia. Anesth Analg 2010; 110: 1305-1309. DOI: 10.1213/ANE.0b013e3181d27b30. PubMed PMID: 20142349

17 Lee EW, Thai S, Kee ST. Irreversible electroporation: a novel imageguided cancer therapy. Gut Liver 2010; 4 Suppl 1: S99-S104. DOI: 10.5009/gnl.2010.4.S1.S99. PubMed PMID: 21103304; PMCID: PMC2989557

18 Cannon R, Ellis S, Hayes D et al. Safety and early efficacy of irreversible electroporation for hepatic tumors in proximity to vital structures. J Surg Oncol 2013; 107: 544-549. DOI: 10.1002/jso.23280. PubMed PMID: 23090720

19 Narayanan G. Irreversible electroporation for treatment of liver cancer. Gastroenterol Hepatol (N Y) 2011; 7 (5): 313-316. PubMed PMID: 21857833; PMCID: PMC3127037

20 Nielsen K, Scheffer HJ, Vieveen JM et al. Anaesthetic management during open and percutaneous irreversible electroporation. $\mathrm{Br} \mathrm{J}$ Anaesth 2014; 113: 985-992. DOI: 10.1093/bja/aeu256. PubMed PMID: 25173767

21 Thomson KR, Cheung W, Ellis SJ et al. Investigation of the safety of irreversible electroporation in humans. J Vasc Interv Radiol 2011; 22: 611-621. DOI: 10.1016/j.jvir.2010.12.014. PubMed PMID: 21439847
22 Appelbaum L, Ben-David E, Sosna J et al. US findings after irreversible electroporation ablation: radiologic-pathologic correlation. Radiology 2012; 262: 117-125. DOI: 10.1148/radiol.11110475. PubMed PMID: 22106355

23 Scheffer HJ, Nielsen K, van Tilborg AA et al. Ablation of colorectal liver metastases by irreversible electroporation: results of the COLDFIRE-I ablate-and-resect study. Eur Radiol 2014; 24: 2467-2475. DOI: 10.1007| s00330-014-3259-x. PubMed PMID: 24939670

24 Cheung $W$, Kavnoudias $H$, Roberts $S$ et al. Irreversible electroporation for unresectable hepatocellular carcinoma: initial experience and review of safety and outcomes. Technol Cancer Res Treat 2013; 12: 233 -241. DOI: 10.7785/tcrt.2012.500317. PubMed PMID: 23369152

25 Lencioni R, Izzo F, Crocetti $L$ et al. A prospective, multicenter phase I clinical trial using irreversible electroporation for the treatment of early stage HCC. J Vasc Interv Radiol 2012; 23: 1114. DOI: 10.1016/j. jvir.2012.05.018

26 Eisele RM, Chopra SS, Glanemann M et al. Risk of local failure after ultrasound guided irreversible electroporation of malignant liver tumors. Interv Med Appl Sci 2014; 6: 147-153. DOI: 10.1556/IMAS.6.2014.4.2. PubMed PMID: 25598987; PMCID: PMC4274353

27 Silk MT, Wimmer T, Lee KS et al. Percutaneous ablation of peribiliary tumors with irreversible electroporation. J Vasc Interv Radiol 2014; 25: 112 -118. DOI: 10.1016/j.jvir.2013.10.012. PubMed PMID: 24262034

28 Silk M, Tahour D, Srimathveeravalli $G$ et al. The state of irreversible electroporation in interventional oncology. Semin Intervent Radiol 2014; 31: 111-117. DOI: 10.1055/s-0034-1373785. PubMed PMID: 25053862; PMCID: PMC4078112

29 Kingham TP, Karkar AM, D'Angelica MI et al. Ablation of perivascular hepatic malignant tumors with irreversible electroporation. J Am Coll Surg 2012; 215: 379-387. DOI: 10.1016/j.jamcollsurg.2012.04.029. PubMed PMID: 22704820

30 Bagla S, Papadouris D. Percutaneous irreversible electroporation of surgically unresectable pancreatic cancer: a case report. J Vasc Interv Radiol 2012; 23: 142 -145. DOI: 10.1016/j.jvir.2011.10.002. PubMed PMID: 22221480

31 Martin RC, McFarland K, Ellis $S$ et al. Irreversible electroporation therapy in the management of locally advanced pancreatic adenocarcinoma. J Am Coll Surg 2012; 215: 361-369. DOI: 10.1016/j.jamcollsurg.2012.05.021. PubMed PMID: 22726894

32 Martin RC, McFarland K, Ellis S et al. Irreversible electroporation in locally advanced pancreatic cancer: potential improved overall survival. Ann Surg Oncol 2013; 20 (3): S443-S449. DOI: 10.1245/s10434-0122736-1. PubMed PMID: 23128941

33 Martin RC, Kwon D, Chalikonda $S$ et al. Treatment of 200 locally advanced (stage III) pancreatic adenocarcinoma patients with irreversible electroporation: safety and efficacy. Ann Surg 2015; 262 (3): 486-494; discussion 92 - 94. DOI: 10.1097/SLA.0000000000001441. PubMed PMID: 26258317

34 Martin RC, Philips P, Ellis $S$ et al. Irreversible electroporation of unresectable soft tissue tumors with vascular invasion: effective palliation. BMC Cancer 2014; 14: 540. DOI: 10.1186/1471-2407-14-540. PubMed PMID: 25064086; PMCID: PMC4124136.

35 Kwon $D$, McFarland $K$, Velanovich $V$ et al. Borderline and locally advanced pancreatic adenocarcinoma margin accentuation with intraoperative irreversible electroporation. Surgery 2014; 156: 910-920. DOI: 10.1016/j.surg.2014.06.058. PubMed PMID: 25239345

36 Paiella S, Butturini G, Frigerio I et al. Safety and feasibility of Irreversible Electroporation (IRE) in patients with locally advanced pancreatic cancer: results of a prospective study. Dig Surg 2015; 32: 90-97. DOI: 10.1159/000375323. PubMed PMID: 25765775

37 Kluger MD, Epelboym I, Schrope BA et al. Single-Institution Experience with Irreversible Electroporation for T4 Pancreatic Cancer: First $50 \mathrm{~Pa}-$ tients. Ann Surg Oncol 2015; DOI: 10.1245/s10434-015-5034-X. PubMed PMID: 26714959

38 Narayanan G, Hosein PJ, Arora G et al. Percutaneous irreversible electroporation for downstaging and control of unresectable pancreatic adenocarcinoma. J Vasc Interv Radiol 2012; 23 (12): 1613-1621. DOI: 10.1016/j.jvir.2012.09.012. PubMed PMID: 23177107

39 Moir J, White SA, French JJ et al. Systematic review of irreversible electroporation in the treatment of advanced pancreatic cancer. Eur J Surg Oncol 2014; 40 (12): 1598-1604. DOI: 10.1016/j.ejso.2014.08.480 PubMed PMID: 25307210

40 Usman M, Moore W, Talati $R$ et al. Irreversible electroporation of lung neoplasm: a case series. Med Sci Monit 2012; 18 (6): CS43-CS47. PubMed PMID: 22648257; PMCID: PMC3560719 
41 Ricke J, Jürgens JH, Deschamps F et al. Irreversible Electroporation (IRE) Fails to Demonstrate Efficacy in a Prospective Multicenter Phase II Trial on Lung Malignancies: The ALICE Trial. Cardiovasc Intervent Radiol 2015; DOI: 10.1007/s00270-014-1049-0. PubMed PMID: 25609208

42 Pech M, Janitzky A, Wendler IJ et al. Irreversible electroporation of renal cell carcinoma: a first-in-man phase I clinical study. Cardiovasc Intervent Radiol 2011; 34: 132-138. DOI: 10.1007/s00270-010-9964-1. PubMed PMID: 20711837

43 Wendler JJ, Ricke J, Pech $M$ et al. First Delayed Resection Findings After Irreversible Electroporation (IRE) of Human Localised Renal Cell Carcinoma (RCC) in the IRENE Pilot Phase 2a Trial. Cardiovasc Intervent Radiol 2015; DOI: 10.1007/s00270-015-1200-6. PubMed PMID: 26341653.

44 Onik G, Rubinsky B. Irreversible Electroporation: First Patient Experience Focal Therapy of Prostate Cancer. Irreversible Electroporation: Springer Berlin Heidelberg2010. p. 235-247

45 Brausi M, Giliberto G, Simonini $G$ et al. Irreversible electroporation (IRE), a novel technique for focal ablation of prostate cancer (PCa): results of a interim pilot safety study in low risk patients with Pca. Presented at EAU. Vienna: 2011

46 van den Bos W, de Bruin DM, Muller BG et al. The safety and efficacy of irreversible electroporation for the ablation of prostate cancer: a multicentre prospective human in vivo pilot study protocol. BMJ Open 2014; 4: e006382. DOI: 10.1136/bmjopen-2014-006382. PubMed PMID: 25354827; PMCID: PMC4216863

47 van den Bos W, de Bruin DM, Jurhill RR et al. The correlation between the electrode configuration and histopathology of irreversible electro- poration ablations in prostate cancer patients. World J Urol 2015; DOI: 10.1007/s00345-015-1661-x. PubMed PMID: 26296371

48 van den Bos W, de Bruin DM, van Randen A et al. MRI and contrast-enhanced ultrasound imaging for evaluation of focal irreversible electroporation treatment: results from a phase I-II study in patients undergoing IRE followed by radical prostatectomy. Eur Radiol 2015; DOI: 10.1007/s00330-015-4042-3. PubMed PMID: 26449559

49 Ting $F$, Tran $M$, Böhm $M$ et al. Focal irreversible electroporation for prostate cancer: functional outcomes and short-term oncological control. Prostate Cancer Prostatic Dis 2015; DOI: 10.1038/pcan.2015.47. PubMed PMID: 26458959

50 Trotti A, Colevas AD, Setser A et al. CTCAE v3.0: development of a comprehensive grading system for the adverse effects of cancer treatment. Semin Radiat Oncol 2003; 13: 176-181. DOI: 10.1016/S10534296(03)00031-6. PubMed PMID: 12903007

51 Valerio M, Stricker PD, Ahmed HU et al. Initial assessment of safety and clinical feasibility of irreversible electroporation in the focal treatment of prostate cancer. Prostate Cancer Prostatic Dis 2014; 17 (4): 343 -347. DOI: 10.1038/pcan.2014.33. PubMed PMID: 25179590; PMCID: PMC4227889

52 van den Bos W, Muller BG, de la Rosette JJ. A randomized controlled trial on focal therapy for localized prostate carcinoma: hemiablation versus complete ablation with irreversible electroporation. J Endourol 2013; 27: 262 -264. DOI: 10.1089/end.2013.1568. PubMed PMID: 23469828

53 Narayanan G, Froud T, Lo K et al. Pain analysis in patients with hepatocellular carcinoma: irreversible electroporation versus radiofrequency ablation-initial observations. Cardiovasc Intervent Radiol 2013; 36: 176-182. DOI: 10.1007/s00270-012-0426-9. PubMed PMID: 22752100 